\title{
The IUCN Red List of Threatened Species: an assessment of coral reef fishes in the US Pacific Islands
}

\author{
B. J. Zgliczynski • I. D. Williams • R. E. Schroeder • \\ M. O. Nadon • B. L. Richards $\cdot$ S. A. Sandin
}

Received: 29 April 2012 / Accepted: 6 February 2013/Published online: 26 February 2013

(C) The Author(s) 2013. This article is published with open access at Springerlink.com

\begin{abstract}
Widespread declines among many coral reef fisheries have led scientists and managers to become increasingly concerned over the extinction risk facing some species. To aid in assessing the extinction risks facing coral reef fishes, large-scale censuses of the abundance and distribution of individual species are critically important. We use fisheries-independent data collected as part of the NOAA Pacific Reef Assessment and Monitoring Program from 2000 to 2009 to describe the range and density across the US Pacific of coral reef fishes included on The International Union for the Conservation of Nature's (IUCN) 2011 Red List of Threatened Species. Forty-five species, including sharks, rays, groupers, humphead wrasse
\end{abstract}

Communicated by Biology Editor Dr. Hugh Sweatman

Electronic supplementary material The online version of this article (doi:10.1007/s00338-013-1018-0) contains supplementary material, which is available to authorized users.

B. J. Zgliczynski $(\bowtie) \cdot$ S. A. Sandin

Scripps Institution of Oceanography, Center for Marine

Biodiversity and Conservation, 9500 Gilman Drive, La Jolla, CA 92083-0202, USA

e-mail: bzgliczy@ucsd.edu

I. D. Williams - B. L. Richards

NOAA Fisheries, Pacific Islands Fisheries Science Center, 2570

Dole St., Honolulu, HI 96822, USA

R. E. Schroeder

NOAA Fisheries, Pacific Islands Regional Office, 1601

Kapiolani Blvd. Suite 1110, Honolulu, HI 96814, USA

M. O. Nadon

NOAA-Joint Institute for Marine and Atmospheric Research, University of Hawaii, 1000 Pope Road, Honolulu, HI 96822, USA
(Cheilinus undulatus), and bumphead parrotfish (Bolbometopon muricatum), included on the IUCN List, were recorded in the US Pacific Islands. Most species were generally rare in the US Pacific with the exception of a few species, principally small groupers and reef sharks. The greatest diversity and densities of IUCN-listed fishes were recorded at remote and uninhabited islands of the Pacific Remote Island Areas; in general, lower densities were observed at reefs of inhabited islands. Our findings complement IUCN assessment efforts, emphasize the efficacy of large-scale assessment and monitoring efforts in providing quantitative data on reef fish assemblages, and highlight the importance of protecting populations at remote and uninhabited islands where some species included on the IUCN Red List of Threatened Species can be observed in abundance.

Keywords IUCN - Coral reef fishes - NOAA Species of Concern · Humphead wrasse (Cheilinus undulatus) ·

Bumphead parrotfish (Bolbometopon muricatum) . Grouper (Serranidae)

\section{Introduction}

Coral reefs are threatened by a host of human activities. Among these, fishing exerts significant and direct impacts on many coral reef fish assemblages (Jackson et al. 2001; Friedlander and DeMartini 2002; Sandin et al. 2008). Reef fishes have long supported subsistence and artisanal fisheries with the earliest record of fishing of coastal habitats traced back at least 35,000 yrs in the western Pacific (Allen et al. 1989). Today, coral reefs continue to support subsistence fisheries and millions of people depend directly on the harvested resources (Zeller et al. 2006). Financially, coral 
reef ecosystems support commercial fisheries estimated to be worth over $\$ 5$ billion per year (Cesar et al. 2003).

Despite their importance, the complexity of coral reef fisheries provides many challenges for the development of management strategies aimed to maintain sustainable fisheries and other ecosystem services. Coral reef fisheries tend to exploit multiple species (Jennings and Polunin 1996a), with the primary targets oftentimes being large-bodied species such as sharks, groupers, snappers, jacks, parrotfishes, and wrasses (Roberts 1995; Jennings and Kaiser 1998; Pauly et al. 1998; Choat et al. 2006; DeMartini et al. 2008). Further, the life history characteristics of many species render them particularly vulnerable to overexploitation. Many large-bodied species tend to be slow-growing, long-lived, have delayed reproductive development, and some form mass aggregations when they spawn (Choat et al. 2006; Tupper 2007; Sadovy de Mitcheson et al. 2008; Colin 2010). Large-bodied species play a critical role in structuring marine ecosystems (Bascompte et al. 2005; Estes et al. 2011), and severe reductions in their biomass have detrimental ecological and economic effects (Pauly et al. 1998; Jackson et al. 2001; Friedlander and DeMartini 2002; Myers and Worm 2003; Sandin et al. 2008). Therefore, knowing the distribution and relative abundance of these species is of critical importance to the development of effective management strategies.

In 1994, the International Union for Conservation of Nature (IUCN), aided by its Species Survival Commission (SSC), developed and adopted a standardized approach for assessing the extinction risk of species and biodiversity in both terrestrial and aquatic environments. Methods and criteria produced by the SSC were used by the IUCN to categorize Red-listed species (Baillie and Groombridge 1996). In general, assessment criteria incorporate estimates of current and historical population size and geographic range to assign species to one of nine categories of risk. As of 2011, the ICUN Red List categories (in order of descending risk) are extinct, extinct in the wild, critically endangered, endangered, vulnerable, near threatened, least concern, data deficient, and not evaluated. The IUCN Red List of Threatened Species (hereafter IUCN List) has been widely adopted as the basis for identifying species at risk and developing programs to conserve biodiversity (Rodrigues et al. 2006; Mace et al. 2008). Although some assessment criteria used by the United States under the Endangered Species Act (ESA) are similar to those used by the IUCN, the listing process under the ESA incorporates additional criteria and listed species are afforded legal protection administered by either the US Fish and Wildlife Service and the National Oceanic and Atmospheric Administration (National Research Council 1995).

The purpose of this paper is to describe the geographic distribution and density across the US Pacific of shallowwater coral reef fishes included on the 2011 IUCN Red List (across all assessment categories identified above), including the two Indo-Pacific coral reef species identified by NOAA as Species of Concern. We use underwater visual survey data collected as part of the NOAA Pacific Reef Assessment and Monitoring Program (RAMP), a large-scale effort to monitor the status of coral reefs across much of the US Pacific. By design, NOAA Pacific RAMP allocates monitoring effort broadly across space (sampling over 40 islands at least once every 2 yrs) and thus lacks high replication at the within-island scale. As such, the ability to resolve temporal trends is limited to functional group assessments (e.g., total fish biomass) or to long-term changes (e.g., trends over decades), but the power of the sampling lies in the high replication at the island scale for each of these assessments. We provide information on the density of sharks, rays, groupers, the bumphead parrotfish (Bolbometopon muricatum), and the humphead wrasse (Cheilinus undulatus). Additionally, we compare densities of these species between inhabited and uninhabited US Pacific Islands.

\section{Materials and methods}

\section{Study area}

Biennial surveys were conducted from 2000 to 2009 at 40 US Pacific Islands as part of the NOAA Pacific RAMP (Table 1; Fig. 1). Sites included islands under US jurisdiction within four geographic regions: American Samoa, the Hawaiian Archipelago, the Mariana Archipelago, and the Pacific Remote Island Areas (PRIA). These islands span much of the central and western Pacific and encompass $3,363 \mathrm{~km}^{2}$ of shallow-water ( $<10$ fathom) habitat (Rohmann et al. 2005). Islands are exposed to varying levels of anthropogenic disturbance, influenced by their degree of inhabitation and distance from population centers. Some islands, such as Oahu in the Hawaiian Archipelago, Guam in the Mariana Archipelago, and Tutuila in American Samoa are densely populated islands with heavily exploited fisheries resources, while some other islands are remote, uninhabited, and relatively uninfluenced by direct human disturbances (Fig. 1). Islands were classified as either "inhabited" or "uninhabited," based on their respective resident populations and level of fisheries management as described by Williams et al. (2011). In some instances, islands classified as uninhabited had or continue to have small resident populations of $<25$ people, with two island atolls (Midway and Wake) having populations slightly higher during the survey period (Table 1). Although some islands classified as uninhabited had small resident populations, the level of fisheries exploitation at these islands was considered nonexistent, because residents 
of the island during the survey period were caretakers, contract staff, or field researchers, and fishing in surrounding shallow-water habitats was restricted or infrequent. Of the 40 islands and reefs included in this study, 15 islands were classified as inhabited and 25 as uninhabited.

\section{Survey methods}

Two underwater survey techniques were used to estimate the density of diurnally active reef fishes. These included towed-diver survey (TDS) and belt transect (BLT) methodologies. All divers collecting data were trained in the identification and size estimation of fishes following protocols outlined by NOAA Pacific RAMP (Richards et al. 2011). Surveys were restricted to the upper forereef slope at depths shallower than $30 \mathrm{~m}$ with a majority of surveys conducted at depths of $12-15 \mathrm{~m}$.

The TDS method consisted of a pair of SCUBA divers being towed $\sim 60 \mathrm{~m}$ behind a small boat at a speed of $\sim 1.5 \mathrm{kts}$ and at depths typically between 10 and $20 \mathrm{~m}$ (Richards et al. 2011). Divers maneuvered towboards 1-3 $\mathrm{m}$ above the benthos, tallying all fishes $\geq 50 \mathrm{~cm}$ total length (TL) that enter a $10-\mathrm{m}$ wide swath centered on the diver. Fish species were recorded to the finest recognizable taxonomic level (typically species) and size was estimated to the nearest $5 \mathrm{~cm}$ TL. Each TDS is $50 \mathrm{~min}$ in duration (10, 5-min segments) and covered an average of about $2.2 \mathrm{~km}$ of linear habitat $\left(22,000 \mathrm{~m}^{2}\right.$ survey area). As such, the TDS method is spatially expansive and results in greater statistical power and higher frequency of encounter than more spatially constrained survey techniques when estimating the density and spatial distribution of rare, large-bodied reef fishes (Richards et al. 2011).

The BLT surveys consisted of a pair of divers conducting three 25-m strip transects, using protocols detailed elsewhere (Friedlander and DeMartini 2002; DeMartini et al. 2008; Friedlander et al. 2010). To summarize, individual fishes were identified to species and length (TL) was estimated to the nearest 5-cm size class. Fish abundance estimates were made by means of two passes for each $25-\mathrm{m}$ transect. The pair of divers surveyed an $8-\mathrm{m}$ width $\left(200 \mathrm{~m}^{2}\right.$ area) for individuals $\geq 20 \mathrm{~cm}$ TL on an outward swim, and a 4-m width $\left(100 \mathrm{~m}^{2}\right.$ area) for species $<20 \mathrm{~cm}$ TL on a return swim.

\section{Data analyses}

Data from TDS and BLT methods were used to estimate size-specific numerical density for species of interest. Maximum body size of each species, based on published estimates and online sources, was used to determine which of these methods was appropriate for species-specific density estimates (Randall 2005, 2010; Froese and Pauly 2010). Fishes reaching a published maximum TL of
$100 \mathrm{~cm}$ or greater were classified as large-bodied, and TDS data were used to estimate the density of these species. Fishes reaching a maximum TL $<100 \mathrm{~cm}$ were classified as smaller-bodied, and BLT data were used to estimate densities of these species. As such, larger-bodied species were assessed using a more spatially expansive method with densities reported as individuals $\mathrm{km}^{-2}$, while smallerbodied species were sampled using a more comprehensive but spatially constrained method with densities reported as individuals $\mathrm{ha}^{-1}$. Detailed summaries of the mean and maximum size of each species using the results of TDS and BLT surveys are provided at the island level as a series of tables for each region in the Electronic Supplementary Material. To maintain sufficient statistical power, islands with a total survey effort of $<9$ TDS or $<7$ BLT were eliminated from the analyses.

Species included in this study were selected based on three factors: (1) inclusion on the 2011 IUCN Red List of Threatened Species (IUCN 2011), (2) biogeographic ranges encompassing the US Pacific Islands confirmed through RAMP surveys, and (3) inhabiting shallow-moderate $(<30 \mathrm{~m})$ depth reef habitats. Web-based and published sources were used to identify the geographic ranges and ecological habitats of IUCN-listed species observed in the US Pacific Islands (Myers 1999; Randall 2005, 2010; Froese and Pauly 2010). A list of the 45 species meeting all three factors identified above is presented in Table 2.

Visual estimates of species density collected from TDS and BLT methods were non-normally distributed at both island and regional scales. For abundant species and species groups, region (or island)-specific densities are presented as means with standard errors using all available survey data. However, for statistical comparisons of groups, transforming the data and applying parametric techniques to estimate population parameters, including explicit descriptions of variability, was not practical because of the rarity of many species and zero-inflated nature of the data. Additionally, survey effort for the TDS and BLT methods varied among islands throughout the survey period (Table 1), which complicated simple parametric comparisons of island mean densities. A statistical bootstrapping approach (Efron and Tibshirani 1986; Chernick 2008) was used to evaluate differences in the mean density of fishes between groups of inhabited and uninhabited islands within each region while accounting for the non-normality of the data and to standardize survey effort across islands. The bootstrapping analysis was based on island-specific survey data on density for each species combined over survey years. TDS data were used for largebodied species and BLT data for smaller-bodied species. Each survey provided an estimate of mean density, and the number of density estimates varied among islands and survey methods (Table 1). 
Table 1 Sampling effort for surveys conducted as part of the NOAA Pacific Reef Assessment and Monitoring Program from 2000 to 2009

\begin{tabular}{|c|c|c|c|c|c|}
\hline Region & Island/reef & $\begin{array}{l}\text { Reef area } \\
\left(\mathrm{km}^{2}\right)^{\mathrm{a}}\end{array}$ & $\begin{array}{l}\text { Cruise } \\
\text { visits }\end{array}$ & $\begin{array}{l}\text { Number of TDS } \\
\left(\text { area surveyed, } \mathrm{km}^{2} \text { ) }\right.\end{array}$ & $\begin{array}{l}\text { Number of BLT } \\
(\text { area surveyed, ha) }\end{array}$ \\
\hline \multirow[t]{6}{*}{ American Samoa } & Ofu \& Olosega & 3.6 & 4 & $62(1.3)$ & $34(1.0 / 2.0)$ \\
\hline & Tau & 3.8 & 4 & $50(1.2)$ & $33(0.9 / 1.9)$ \\
\hline & Tutuila & 35.8 & 4 & $122(2.6)$ & $72(2.1 / 4.3)$ \\
\hline & Rose & 7.9 & 4 & $60(1.0)$ & $36(1.0 / 2.1)$ \\
\hline & Swains & 2.4 & 4 & $42(0.8)$ & $28(0.8 / 1.6)$ \\
\hline & American Samoa total & & & $336(6.9)$ & $203(6.1 / 12.2)$ \\
\hline \multirow[t]{16}{*}{ Hawaiian Archipelago } & Hawaii & 193.7 & 3 & $74(1.5)$ & $60(1.8 / 3.6)$ \\
\hline & Kauai & 178.8 & 3 & $56(1.1)$ & $28(0.8 / 1.6)$ \\
\hline & Lanai & 46.3 & 3 & $33(0.8)$ & $18(0.5 / 1.0)$ \\
\hline & Maui & 164.6 & 3 & $65(1.4)$ & $35(1.0 / 2.1)$ \\
\hline & Molokai & 161.6 & 3 & $24(0.6)$ & $13(0.3 / 0.7)$ \\
\hline & Niihau-Lehua & 6.7 & 3 & $47(1.0)$ & $26(0.7 / 1.5)$ \\
\hline & Oahu & 374.8 & 3 & $40(0.8)$ & $19(0.5 / 1.1)$ \\
\hline & French Frigate & 469.4 & 8 & $62(1.3)$ & $31(0.9 / 1.8)$ \\
\hline & Kure & 90.2 & 6 & $49(0.9)$ & $29(0.8 / 1.7)$ \\
\hline & Laysan & 26.4 & 6 & $31(0.5)$ & $23(0.6 / 1.3)$ \\
\hline & Lisianski & 215.6 & 6 & $71(1.3)$ & $44(1.3 / 2.6)$ \\
\hline & Maro & 217.5 & 7 & $82(1.5)$ & $48(1.4 / 2.8)$ \\
\hline & Midway & 85.4 & 5 & $47(0.9)$ & $21(0.6 / 1.2)$ \\
\hline & Necker & 9.1 & 4 & $12(0.2)$ & $9(0.2 / 0.5)$ \\
\hline & Pearl \& Hermes & 374.5 & 7 & $78(1.6)$ & $32(0.9 / 1.9)$ \\
\hline & Hawaiian Archipelago total & & & $771(15.5)$ & $436(13.1 / 26.2)$ \\
\hline \multirow[t]{14}{*}{ Mariana Archipelago } & Guam & 91.3 & 4 & $84(1.8)$ & $39(1.1 / 2.3)$ \\
\hline & Rota & 12.1 & 4 & $44(0.9)$ & $23(0.6 / 1.3)$ \\
\hline & Saipan & 56.8 & 4 & $59(1.2)$ & $30(0.9 / 1.8)$ \\
\hline & Tinian & 14.7 & 4 & $37(0.8)$ & $19(0.5 / 1.1)$ \\
\hline & Aguijan & 2.6 & 4 & $18(0.4)$ & $8(0.2 / 0.4)$ \\
\hline & Agrihan & 8.6 & 4 & $34(0.7)$ & $18(0.5 / 1.0)$ \\
\hline & Alamagan & 3.2 & 4 & $24(0.5)$ & $11(0.3 / 0.6)$ \\
\hline & Asuncion & 0.5 & 4 & $21(0.4)$ & $15(0.4 / 0.9)$ \\
\hline & Farallon de Pajaros & 0.8 & 4 & $19(0.4)$ & $13(0.3 / 0.7)$ \\
\hline & Guguan & 1.1 & 4 & $18(0.3)$ & $11(0.3 / 0.6)$ \\
\hline & Maug & 2.1 & 4 & $44(0.8)$ & $34(1.0 / 2.0)$ \\
\hline & Pagan & 11.1 & 4 & $69(1.3)$ & $33(0.9 / 1.9)$ \\
\hline & Sarigan & 1.9 & 4 & $22(0.4)$ & $12(0.3 / 0.7)$ \\
\hline & Mariana Archipelago total & & & $493(9.8)$ & $266(8.0 / 16.0)$ \\
\hline \multirow{8}{*}{$\begin{array}{l}\text { Pacific Remote Island } \\
\text { Areas (PRIAs) }\end{array}$} & Baker & 5.2 & 5 & $29(0.5)$ & $29(0.8 / 1.7)$ \\
\hline & Howland & 3 & 5 & $30(0.7)$ & $26(0.7 / 1.5)$ \\
\hline & Jarvis & 3 & 5 & $43(0.8)$ & $29(0.8 / 1.7)$ \\
\hline & Johnston & 150.1 & 2 & $35(0.5)$ & $7(0.2 / 0.4)$ \\
\hline & Kingman & 20.9 & 5 & $53(0.8)$ & $13(0.3 / 0.7)$ \\
\hline & Palmyra & 47.2 & 5 & $64(1.2)$ & $39(1.1 / 2.3)$ \\
\hline & Wake & 22.9 & 3 & $51(1.0)$ & $36(1.0 / 2.1)$ \\
\hline & PRIAs total & & & $305(5.4)$ & $179(5.4 / 10.8)$ \\
\hline
\end{tabular}

Uninhabited islands within each region are italicized

TDS towed-diver surveys BLT belt transect surveys

${ }^{\text {a }}$ Area calculated from shoreline to 10 fathom line (Rohmann et al. 2005)

${ }^{\mathrm{b}}$ Survey areas for the BLT were calculated using an $8-\mathrm{m}$ width $\left(200 \mathrm{~m}^{2}\right.$ area) for individuals $\geq 20 \mathrm{~cm}$ TL, and a 4-m width (100 $\mathrm{m}^{2}$ area) for species $<20 \mathrm{~cm} \mathrm{TL}$ 
To create a bootstrap replicate, a sample of density estimates was drawn randomly with replacement for each island from the total pool of estimates for the island (Table 1). Bootstrap sample sizes were 9 surveys for TDS and 7 surveys for BLT. Within each region, island-specific bootstrap means were assigned to one of two habitation categories-inhabited and uninhabited islands. Within each region, the average bootstrap density was computed over all inhabited islands in the region and similarly for the uninhabited islands, and the difference between the two averages was calculated.

The statistical resampling across all islands was completed 10,000 times, generating species-specific bootstrap statistical distributions of density within each region for each habitation stratum and the differences in average density between the habitation strata. In each case, $95 \%$ confidence intervals for mean density using the appropriate bootstrap distribution by calculating the 2.5 and $97.5 \%$ and setting them as the lower and upper $95 \%$ limits, respectively.
Regional differences in density for each species between inhabited or uninhabited island groups were determined by subtracting mean densities at inhabited islands from the mean densities of uninhabited island groups. Positive mean differences denoted that uninhabited island groups yielded a higher mean density of fishes while negative mean differences denoted that an uninhabited island group yielded a lower mean density of fishes than their inhabited counterparts. Significant differences in regional means were estimated by calculating the number of times that subsampled values differed between regional groups (either positive or negative), expressing the quantile range of the distribution of results (e.g., 0, 0.001, 0.01, 0.05, 0.25, 0.5, 0.75, 0.95, $0.99,0.999$, and 1.0 quantiles). If $\geq 95 \%$ of the distribution of data (positive or negative) fell within the quantile range, it was deemed significant and the corresponding level of significance was assigned $(<0.05,<0.01$, or $<0.001)$. Analyses were conducted using R version 2.15.1 (The R Foundation for Statistical Computing 2012).

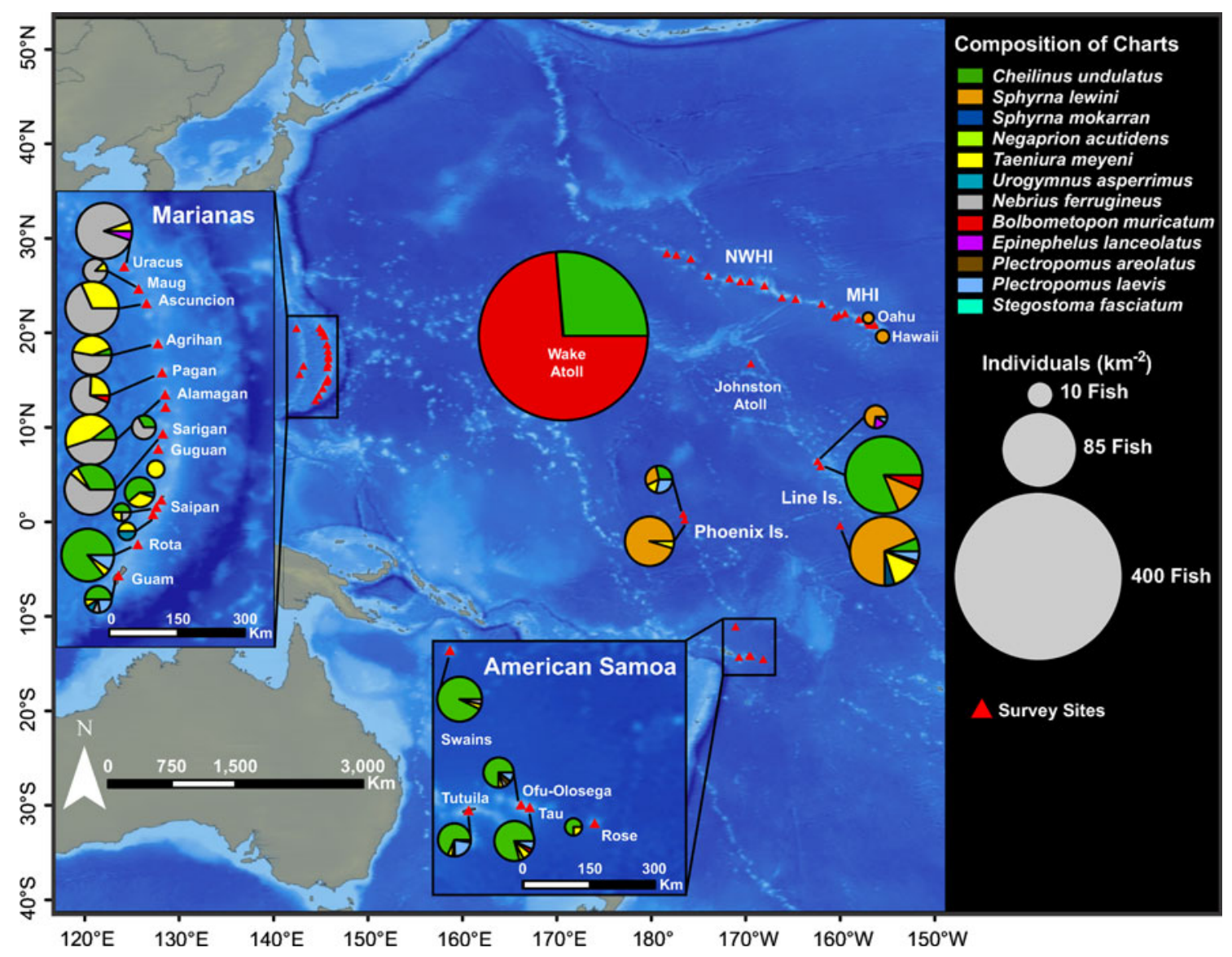

Fig. 1 Chart of the US Pacific Islands identifying islands surveyed as part of the NOAA Pacific RAMP. Figure identifies the total mean density of IUCN Red-listed species facing the greatest threat of extinction (2011 IUCN Red List Categories: endangered and threatened). Data are based on towed-diver surveys conducted from 2000 to 2009. Mean densities of fishes are indicated by pie diagrams; the size of individual pies is proportional to the number of individuals observed $\mathrm{km}^{-2}$ 
Table 2 Fish species included on the 2011 IUCN Red List of Threatened Species observed in the US Pacific Islands during BLT and TDS completed on a biennial or annual basis from 2000 to 2009

\begin{tabular}{|c|c|c|c|c|c|c|c|c|c|}
\hline \multirow[t]{2}{*}{ Family } & \multirow[t]{2}{*}{ Species } & \multicolumn{5}{|c|}{ Ecological information $^{a}$} & \multicolumn{3}{|c|}{ IUCN assessment ${ }^{\mathrm{b}}$} \\
\hline & & $\begin{array}{l}\text { Max length } \\
(\mathrm{cm} \mathrm{TL})\end{array}$ & $\begin{array}{l}\text { Depth } \\
\text { range }(\mathrm{m})\end{array}$ & Habitat $^{\mathrm{c}}$ & $\begin{array}{l}\text { Observed } \\
\text { region }^{\mathrm{d}}\end{array}$ & $\begin{array}{l}\text { Published } \\
\text { range }^{d}\end{array}$ & Status ${ }^{\mathrm{e}}$ & Years & Trend \\
\hline Ginglymostomatidae & Nebrius ferrugineus & 320 & $1-70$ & RA & $\mathrm{A}, \mathrm{M}, \mathrm{P}$ & $\mathrm{A}, \mathrm{M}, \mathrm{P}$ & VU & 2003 & Decreasing \\
\hline Stegostomatidae & Stegostoma fasciatum & 235 & $0-63$ & RA & A & $\mathrm{A}, \mathrm{M}, \mathrm{P}$ & VU & 2003 & Decreasing \\
\hline \multirow[t]{6}{*}{ Carcharhinidae } & Carcharhinus amblyrhynchos & 255 & $0-1,000$ & RA, O & $\mathrm{A}, \mathrm{H}, \mathrm{M}, \mathrm{P}$ & $\mathrm{A}, \mathrm{H}, \mathrm{M}, \mathrm{P}$ & NT & 2005 & Unknown \\
\hline & C. galapagensis & 370 & $0-286$ & RA & $\mathrm{A}, \mathrm{H}, \mathrm{P}$ & $\mathrm{A}, \mathrm{H}, \mathrm{P}$ & NT & 2003 & Unknown \\
\hline & C. melanopterus & 200 & $20-75$ & RA & $\mathrm{A}, \mathrm{M}, \mathrm{P}$ & $\mathrm{A}, \mathrm{H}, \mathrm{M}, \mathrm{P}$ & NT & 2005 & Decreasing \\
\hline & Galeocerdo cuvier & 750 & $0-371$ & $\mathrm{~B}, \mathrm{O}$ & $\mathrm{H}, \mathrm{P}$ & $\mathrm{A}, \mathrm{H}, \mathrm{M}, \mathrm{P}$ & NT & 2005 & Unknown \\
\hline & Negaprion acutidens & 380 & $0-92$ & RA & A & $\mathrm{A}, \mathrm{M}, \mathrm{P}$ & VU & 2003 & Decreasing \\
\hline & Triaenodon obesus & 213 & $1-330$ & RA & $\mathrm{A}, \mathrm{H}, \mathrm{M}, \mathrm{P}$ & $\mathrm{A}, \mathrm{H}, \mathrm{M}, \mathrm{P}$ & NT & 2005 & Unknown \\
\hline \multirow[t]{2}{*}{ Sphyrnidae } & Sphyrna lewini & 430 & $0-512$ & $\mathrm{PO}, \mathrm{O}$ & $\mathrm{H}, \mathrm{P}$ & $\mathrm{A}, \mathrm{H}, \mathrm{M}, \mathrm{P}$ & $\mathrm{EN}$ & 2007 & Unknown \\
\hline & S. mokarran & 610 & $1-300$ & $\mathrm{PO}, \mathrm{O}$ & $\mathrm{P}$ & $\mathrm{A}, \mathrm{H}, \mathrm{M}, \mathrm{P}$ & EN & 2007 & Decreasing \\
\hline \multirow[t]{2}{*}{ Dasyatidae } & Taeniura meyeni & 330 & $0-500$ & RA & $\mathrm{A}, \mathrm{M}, \mathrm{P}$ & $\mathrm{A}, \mathrm{M}, \mathrm{P}$ & VU & 2006 & Unknown \\
\hline & Urogymnus asperrimus & 147 & & RA & M & M & VU & 2005 & Unknown \\
\hline Myliobatidae & Aetobatus narinari & 330 & $1-80$ & RA & $\mathrm{A}, \mathrm{H}, \mathrm{M}, \mathrm{P}$ & $\mathrm{A}, \mathrm{H}, \mathrm{M}, \mathrm{P}$ & NT & 2006 & Decreasing \\
\hline Mobulidae & Manta alfredi & $910^{\mathrm{f}}$ & $0-120$ & $\mathrm{RA}, \mathrm{O}$ & $\mathrm{H}, \mathrm{P}$ & $\mathrm{A}, \mathrm{H}, \mathrm{M}, \mathrm{P}$ & VU & 2011 & Unknown \\
\hline \multirow[t]{28}{*}{ Serranidae } & Aethaloperca rogaa & 60 & $1-60$ & RA & $\mathrm{M}, \mathrm{P}$ & M & DD & 2008 & Unknown \\
\hline & Anyperodon leucogrammicus & 65 & $1-80$ & RA & A & $\mathrm{A}, \mathrm{M}, \mathrm{P}$ & $\mathrm{LC}$ & 2008 & Unknown \\
\hline & Cephalopholis argus & 60 & $1-40$ & RA & $\mathrm{A}, \mathrm{H}, \mathrm{M}, \mathrm{P}$ & $\mathrm{A}, \mathrm{H}, \mathrm{M}, \mathrm{P}$ & $\mathrm{LC}$ & 2008 & Stable \\
\hline & C. leopardus & 24 & $1-40$ & RA & $\mathrm{A}, \mathrm{M}, \mathrm{P}$ & $\mathrm{A}, \mathrm{M}, \mathrm{P}$ & $\mathrm{LC}$ & 2008 & Unknown \\
\hline & C. miniata & 45 & $2-150$ & RA & $\mathrm{A}, \mathrm{M}, \mathrm{P}$ & $\mathrm{A}, \mathrm{M}, \mathrm{P}$ & $\mathrm{LC}$ & 2008 & Decreasing \\
\hline & C. sexmaculata & 50 & $6-150$ & RA & $\mathrm{A}, \mathrm{M}, \mathrm{P}$ & $\mathrm{A}, \mathrm{M}, \mathrm{P}$ & $\mathrm{LC}$ & 2008 & Decreasing \\
\hline & C. sonnerati & 57 & $10-150$ & RA & M & $\mathrm{A}, \mathrm{M}, \mathrm{P}$ & $\mathrm{LC}$ & 2008 & Stable \\
\hline & C. spiloparaea & 30 & $15-108$ & RA & $\mathrm{A}, \mathrm{P}$ & $\mathrm{A}, \mathrm{M}, \mathrm{P}$ & $\mathrm{LC}$ & 2008 & Unknown \\
\hline & C. urodeta & 28 & $1-60$ & RA & $\mathrm{A}, \mathrm{M}, \mathrm{P}$ & $\mathrm{A}, \mathrm{M}, \mathrm{P}$ & $\mathrm{LC}$ & 2008 & Unknown \\
\hline & Epinephelus fasciatus & 40 & $4-160$ & RA & $\mathrm{A}, \mathrm{M}, \mathrm{P}$ & $\mathrm{A}, \mathrm{M}, \mathrm{P}$ & $\mathrm{LC}$ & 2008 & Decreasing \\
\hline & E. hexagonatus & 27.5 & $0-30$ & RA & $\mathrm{A}, \mathrm{M}, \mathrm{P}$ & $\mathrm{A}, \mathrm{M}, \mathrm{P}$ & $\mathrm{LC}$ & 2008 & Stable \\
\hline & E. howlandi & 55 & $1-37$ & RA & $\mathrm{A}, \mathrm{M}, \mathrm{P}$ & $\mathrm{A}, \mathrm{M}, \mathrm{P}$ & $\mathrm{LC}$ & 2008 & Unknown \\
\hline & E. lanceolatus & 270 & $4-100$ & RA & $\mathrm{M}, \mathrm{P}$ & $\mathrm{A}, \mathrm{H}, \mathrm{M}, \mathrm{P}$ & VU & 2006 & Decreasing \\
\hline & E. macrospilos & 51 & $1-30$ & RA & $\mathrm{P}$ & $\mathrm{A}, \mathrm{P}$ & LC & 2008 & Unknown \\
\hline & E. maculatus & 60.5 & $2-100$ & RA & $\mathrm{A}, \mathrm{M}$ & $\mathrm{A}, \mathrm{M}, \mathrm{P}$ & $\mathrm{LC}$ & 2008 & Decreasing \\
\hline & E. melanostigma & 35 & $0-30$ & RA & $\mathrm{A}, \mathrm{M}, \mathrm{P}$ & $\mathrm{A}, \mathrm{M}, \mathrm{P}$ & DD & 2008 & Unknown \\
\hline & E. merra & 31 & $0-50$ & RA & $\mathrm{A}, \mathrm{M}, \mathrm{P}$ & $\mathrm{A}, \mathrm{M}, \mathrm{P}$ & $\mathrm{LC}$ & 2008 & Stable \\
\hline & E. polyphekadion & 90 & $1-46$ & $\mathrm{RA}, \mathrm{O}$ & $\mathrm{A}, \mathrm{M}, \mathrm{P}$ & $\mathrm{A}, \mathrm{M}, \mathrm{P}$ & NT & 2006 & Decreasing \\
\hline & E. retouti & 50 & $20-220$ & RA & $\mathrm{P}$ & $\mathrm{A}, \mathrm{M}, \mathrm{P}$ & DD & 2008 & Unknown \\
\hline & E. spilotoceps & 35 & $0-30$ & RA & $\mathrm{A}, \mathrm{P}$ & $\mathrm{A}, \mathrm{P}$ & LC & 2008 & Unknown \\
\hline & E. tauvina & 75 & $1-300$ & $\mathrm{RA}, \mathrm{O}$ & $\mathrm{A}, \mathrm{M}, \mathrm{P}$ & $\mathrm{A}, \mathrm{M}, \mathrm{P}$ & DD & 2008 & Unknown \\
\hline & Gracila albomarginata & 40 & $6-120$ & RA & $\mathrm{A}, \mathrm{M}, \mathrm{P}$ & $\mathrm{A}, \mathrm{M}, \mathrm{P}$ & DD & 2008 & Unknown \\
\hline & Hyporthodus quernus & 122 & $20-380$ & $\mathrm{~B}$ & $\mathrm{H}$ & $\mathrm{H}$ & NT & 2004 & Unknown \\
\hline & Plectropomus areolatus & 73 & $1-20$ & RA & A & $\mathrm{A}, \mathrm{M}, \mathrm{P}$ & VU & 2008 & Decreasing \\
\hline & P. laevis & 125 & $4-100$ & RA & $\mathrm{A}, \mathrm{M}, \mathrm{P}$ & $\mathrm{A}, \mathrm{M}, \mathrm{P}$ & VU & 2008 & Decreasing \\
\hline & P. leopardus & 120 & $3-100$ & $\mathrm{RA}, \mathrm{O}$ & A & M & NT & 2004 & Decreasing \\
\hline & Variola albimarginata & 65 & $4-200$ & RA & $\mathrm{A}, \mathrm{M}$ & $\mathrm{A}, \mathrm{M}$ & $\mathrm{LC}$ & 2008 & Decreasing \\
\hline & V. louti & 83 & $3-250$ & RA & $\mathrm{A}, \mathrm{M}, \mathrm{P}$ & $\mathrm{A}, \mathrm{M}, \mathrm{P}$ & LC & 2008 & Stable \\
\hline Chaetodontidae & Chaetodon flavocoronatus & 12 & $36-75$ & RA & M & M & VU & 1996 & Needs updating \\
\hline Labridae & Cheilinus undulatus $^{\mathrm{g}}$ & 229 & $1-100$ & RA & $\mathrm{A}, \mathrm{M}, \mathrm{P}$ & $\mathrm{A}, \mathrm{M}, \mathrm{P}$ & EN & 2004 & Decreasing \\
\hline
\end{tabular}


Table 2 continued

\begin{tabular}{|c|c|c|c|c|c|c|c|c|c|}
\hline \multirow[t]{2}{*}{ Family } & \multirow[t]{2}{*}{ Species } & \multicolumn{5}{|c|}{ Ecological information ${ }^{\mathrm{a}}$} & \multicolumn{3}{|c|}{ IUCN $_{\text {assessment }}{ }^{\mathrm{b}}$} \\
\hline & & $\begin{array}{l}\text { Max length } \\
(\mathrm{cm} \text { TL) }\end{array}$ & $\begin{array}{l}\text { Depth } \\
\text { range }(\mathrm{m})\end{array}$ & Habitat $^{\mathrm{c}}$ & $\begin{array}{l}\text { Observed } \\
\text { region }^{\mathrm{d}}\end{array}$ & $\begin{array}{l}\text { Published } \\
\text { range }^{\mathrm{d}}\end{array}$ & Status ${ }^{\mathrm{e}}$ & Years & Trend \\
\hline Scaridae & Bolbometopon muricatum ${ }^{\mathrm{g}}$ & 130 & $1-30$ & RA & $\mathrm{A}, \mathrm{M}, \mathrm{P}$ & $\mathrm{A}, \mathrm{M}, \mathrm{P}$ & VU & 2007 & Decreasing \\
\hline \multicolumn{10}{|c|}{${ }^{a}$ FishBase served as the source for ecological information } \\
\hline \multicolumn{10}{|c|}{ b IUCN assessment information is based on the 2011 IUCN Red List of Threatened Species } \\
\hline \multicolumn{10}{|c|}{ c $B$ Benthopelagic, $O$ Oceanodromous, $P O$ Pelagic-oceanic, $R A$ Reef-associated } \\
\hline \multicolumn{10}{|c|}{ d $A$ American Samoa, $H$ Hawaiian Archipelago, $M$ Mariana Archipelago, $P$ Pacific Remote Island Areas } \\
\hline \multicolumn{10}{|c|}{${ }^{\mathrm{e}} N T$ near threatened, $V U$ Vulnerable, $E N$ Endangered, $D D$ data deficient, $L C$ least concern } \\
\hline \multicolumn{10}{|c|}{${ }^{f}$ Disk width } \\
\hline g NOAA & ceern & & & & & & & & \\
\hline
\end{tabular}

\section{Results}

IUCN-listed species in the US Pacific Islands

Forty-five species representing 11 families of fishes included on the IUCN List were observed during RAMP surveys (Table 2). Of the species observed, more than $25 \%$ (13 species) are categorized by the IUCN as endangered or vulnerable, the two highest extinction risk categories observed in this assessment. The humphead wrasse, scalloped hammerhead (Sphyrna lewini), and great hammerhead (Sphyrna mokarran) are the only three species observed during this study that are listed as endangered and are considered to face the greatest risk of extinction. The humphead wrasse is one of two Indo-Pacific coral reef fishes also listed as a NOAA Species of Concern.

Groupers (Serranidae) accounted for more than $60 \%$ (28 species) of the IUCN-listed species encountered during RAMP surveys. However, only 3 of the groupers observed are listed as vulnerable, the second highest risk of extinction. These include the giant grouper (Epinephelus lanceolatus), squaretail coral grouper (Plectropomus areolatus), and black saddled coral grouper ( $P$. laevis). Three additional groupers observed during surveys are assigned to the near-threatened category and considered to be close to qualifying or likely to qualify for one of the threatened categories in the near future. These include the camouflage grouper (Epinephelus polyphekadion), Hawaiian grouper (Hyporthodus [Epinephelus] quernus), and the leopard coral grouper (Plectropomus leopardus). The remaining 22 grouper species represent $49 \%$ of the IUCN-listed species encountered during RAMP surveys and are assigned to the least concern and data-deficient categories.

Sharks and rays from the subclass Elasmobranchii accounted for the second greatest proportion $(31 \%)$ of IUCN-listed species encountered during surveys. Of the 14 species of Elasmobranchs, nearly half (6 species) are requiem sharks (Carcharhinidae), with the lemon shark (Negaprion acutidens) being the only reef shark listed as vulnerable. The two species of hammerhead sharks are listed as endangered, and the remaining sharks and rays observed during surveys are listed as vulnerable (4 species) or near threatened (2 species). A complete list of all 45 IUCN-listed species observed during RAMP surveys is included in Table 2. Additionally, the results from the TDS and BLT surveys are summarized in a series of tables included in Electronic Supplementary Material identifying the mean and maximum size of each species observed at each island during this assessment.

Regional and island trends

At the regional level, the greatest number of IUCN-listed species (39 species) was observed in the PRIA, while the smallest number of species (12 species) was observed in the Hawaiian Archipelago. At the island level, the greatest number of IUCN-listed species was observed at Howland Island (PRIA) with 26 species, followed by Jarvis Island (25 species), Palmyra Atoll (24 species), and Baker Island (20 species), all located within the PRIA. Tutuila, the largest and most densely populated island in American Samoa, was the only non-PRIA island with more than 20 IUCN-listed species observed (21 species). Few species have ranges extending to all four geographic regions. These broad-ranging species included gray reef sharks (Carcharhinus amblyrhynchos, near threatened), whitetip reef sharks (Triaenodon obesus, near threatened), spotted eagle rays (Aetobatus narinari, near threatened), and the peacock hind (Cephalopholis argus, least concern). The peacock hind's distribution includes the inhabited islands of the Hawaiian Archipelago following its deliberate introduction from the Society Islands in 1956 (Randall 1987).

Density of large-bodied species

Total mean density of large-bodied species varied greatly at the regional and island levels (Table 3). The greatest densities of IUCN-listed species were observed in the 
PRIA where the overall mean was 33 individuals $\mathrm{km}^{-2}$ (SE 21). In contrast, the lowest density of IUCN-listed species was observed in American Samoa, that is, two individuals $\mathrm{km}^{-2}$ (SE 1). In the Hawaiian Archipelago and Mariana Archipelago, IUCN-listed species were observed in densities less than a third of those in the PRIA with total mean density of IUCN-listed species being seven individuals $\mathrm{km}^{-2}$ (SE 3) and nine individuals $\mathrm{km}^{-2}$ (SE 5) observed, respectively.

Considerable differences in the mean density of IUCNlisted species were observed between inhabited and uninhabited islands of the Hawaiian and Mariana Archipelagoes (Table 3). The mean density of IUCN-listed species (all species pooled) was fivefold greater at uninhabited islands within the two archipelagoes. Of the 11 IUCN-listed species observed in the Hawaiian Archipelago during TDS, 4 were recorded at significantly greater $(p<0.01)$ densities at uninhabited islands. Those were the gray reef shark, Galapagos shark (Carcharhinus galapagensis), whitetip reef shark, and Hawaiian grouper all of which are listed as near threatened.

In the Mariana Archipelago, 3 IUCN-listed species were observed in significantly greater $(p<0.001)$ densities at uninhabited islands: the tawny nurse shark (Nebrius ferrugineus, near threatened), gray reef shark, and whitetip reef shark. The humphead wrasse was the only IUCN-listed species and NOAA Species of Concern observed in significantly greater $(p<0.05)$ density at inhabited islands in the Mariana Archipelago with 14 individuals observed $\mathrm{km}^{-2}(95 \%$ CI 5,27$)$ compared to 4 individuals observed $\mathrm{km}^{-2}(95 \%$ CI 1, 9) at uninhabited islands within the archipelago. In American Samoa, no significant difference in the mean density of IUCN-listed species was observed between inhabited and uninhabited islands.

\section{Density of high-risk, large-bodied species}

In general, high-risk species listed as endangered or vulnerable were uncommon, with the exception of tawny nurse sharks, blotched fantail rays (Taeniura meyeni), scalloped hammerhead shark, and humphead wrasse (Fig., 1). Tawny nurse sharks and blotched fantail rays were most frequently observed at uninhabited islands of the Mariana Archipelago, with a mean density of 0.16 individuals $\mathrm{km}^{-2}(95 \% \mathrm{CI} 0.10,0.22)$ and 0.06 individuals $\mathrm{km}^{-2}$ (95\% CI 0.02, 0.12), respectively. Scalloped hammerhead sharks were rare throughout all islands but observed in the greatest density in the PRIA at 0.16 individuals $\mathrm{km}^{-2}$ (95\% CI 0, 0.46).

Humphead wrasse was the most widely distributed highrisk species that included all regions except the Hawaiian Archipelago. The greatest densities of humphead wrasse were observed in the PRIA, with a regional mean of 0.26 individuals observed $\mathrm{km}^{-2}$ (95\% CI $0.14,0.42$ ). Within the PRIA, the greatest density was recorded at Wake Atoll with 114 individuals observed $\mathrm{km}^{-2}$ (SE 15). Palmyra Atoll had the second greatest density with 63 individuals observed $\mathrm{km}^{-2}$ (SE 13). Humphead wrasse was also recorded at the southern islands of the Mariana Archipelago and throughout American Samoa. In the Mariana Archipelago, Rota Island had the greatest density of humphead wrasse with 40 individuals observed $\mathrm{km}^{-2}$ (SE 10). Humphead wrasse was also observed at all of the islands in American Samoa with the greatest density observed at Swains Island [29 individuals $\mathrm{km}^{-2}$ (SE 7)].

Bumphead parrotfish (vulnerable), one of two IndoPacific coral reef species listed as a NOAA Species of Concern, were rare or absent in the US Pacific Islands except for at Wake Atoll where their mean density was 297 individuals $\mathrm{km}^{-2}$ (SE 96). Bumphead Parrotfish were also observed at Palmyra Atoll but only at a fraction of what was observed at Wake Atoll, where a mean five fish $\mathrm{km}^{-2}$ (SE 4) was observed. Other sightings of the bumphead parrotfish included Pagan Island (Mariana Archipelago), with two individuals observed, and at Tau and Tutuila (American Samoa), where a single individual was observed at each location.

\section{Density of small-bodied species}

Small-bodied grouper species reaching a maximum TL of $<100 \mathrm{~cm}$ accounted for a majority $(23$ species $)$ of the IUCN-listed species encountered. The yellow-crowned butterflyfish (Chaetodon flavocoronatus, vulnerable) was the only other small-bodied included on the IUCN List and recorded in the US Pacific Islands. In general, small-bodied IUCN-listed species were rare, and mean densities varied at both the regional and island level. Most species were infrequently recorded while a few others were observed in great densities (Table 4).

At the regional level, the highest mean densities of IUCN-listed grouper species were observed in the PRIA with 28 individuals observed ha ${ }^{-1}$ (SE 12). Grouper densities in American Samoa and the Mariana Archipelago were a little more than half of those observed in the PRIA, with mean densities equal to 23 individuals $\mathrm{ha}^{-1}$ (SE 12) and 17 individuals ha ${ }^{-1}$ (SE 10), respectively.

Significant differences in the density of small-bodied grouper species were observed between inhabited and uninhabited islands (Table 4). In American Samoa, five of the 22 IUCN-listed grouper species recorded in the archipelago were observed in significantly greater densities at uninhabited islands. The yellow-edged lyretail grouper (Variola louti, least concern) was the only grouper species observed at significantly greater $(p<0.05)$ densities at inhabited islands with five individuals $\mathrm{ha}^{-1}$ (95\% CI 1, 
Table 3 Summary results of towed-diver surveys using a resampling approach $(n=10,000)$ to evaluate differences (between inhabited and uninhabited regions) in mean densities (individuals $\mathrm{km}^{-2}$ ) of large-bodied fishes ( $>50 \mathrm{~cm}$ TL) included on the IUCN Red List of Threatened Species observed in the US Pacific Islands from 2000 to 2009

\begin{tabular}{|c|c|c|c|c|c|c|c|c|c|}
\hline \multirow[t]{2}{*}{ Status $^{\mathrm{a}}$} & \multirow[t]{2}{*}{ Family } & \multirow[t]{2}{*}{ Species } & \multicolumn{2}{|c|}{ American Samoa } & \multicolumn{2}{|c|}{ Hawaiian Archipelago } & \multicolumn{2}{|c|}{ Mariana Archipelago } & \multirow{2}{*}{$\begin{array}{l}\text { PRIAs } \\
\text { Uninhabited }\end{array}$} \\
\hline & & & Inhabited & Uninhabited & Inhabited & Uninhabited & Inhabited & Uninhabited & \\
\hline \multirow[t]{3}{*}{ EN } & \multirow[t]{2}{*}{ Sphyrnidae } & Sphyrna lewini & 0 & 0 & $\begin{array}{l}0.01 \mathrm{~ns} \\
(0,0.03)\end{array}$ & 0 & 0 & 0 & $\begin{array}{l}0.16 \\
(0,0.46)\end{array}$ \\
\hline & & S. mokarran & 0 & 0 & 0 & 0 & 0 & 0 & $\begin{array}{l}0.01 \\
(0,0.02)\end{array}$ \\
\hline & Labridae & Cheilinus undulatus $^{\mathrm{b}}$ & $\begin{array}{l}0.14 \mathrm{~ns} \\
(0.05,0.03)\end{array}$ & $\begin{array}{l}0.17 \\
(0.03,0.33)\end{array}$ & - & - & $\begin{array}{l}0.14>* \\
(0.05,0.28)\end{array}$ & $\begin{array}{l}0.04 \\
(0,0.09)\end{array}$ & $\begin{array}{l}0.26 \\
(0.14,0.42)\end{array}$ \\
\hline \multirow[t]{9}{*}{ VU } & Ginglymostomatidae & Nebrius ferrugineus & $\begin{array}{l}0 \mathrm{~ns} \\
(0,0.02)\end{array}$ & $\begin{array}{l}0 \\
(0,0.02)\end{array}$ & - & - & $\begin{array}{l}0<* * * \\
(0,0.03)\end{array}$ & $\begin{array}{l}0.16 \\
(0.10,0.22)\end{array}$ & 0 \\
\hline & Stegostomatidae & Stegostoma fasciatum & $\begin{array}{l}0 \mathrm{~ns} \\
(0,0.01)\end{array}$ & 0 & - & - & 0 & 0 & 0 \\
\hline & Carcharhinidae & Negaprion acutidens & $\begin{array}{l}0 \mathrm{~ns} \\
(0,0.01)\end{array}$ & 0 & - & - & 0 & 0 & 0 \\
\hline & \multirow[t]{2}{*}{ Dasyatidae } & Taeniura meyeni & $\begin{array}{l}0.01 \mathrm{~ns} \\
(0,0.05)\end{array}$ & $\begin{array}{l}0 \\
(0,0.03)\end{array}$ & - & - & $\begin{array}{l}0.02 \mathrm{~ns} \\
(0,0.06)\end{array}$ & $\begin{array}{l}0.06 \\
(0.02,0.12)\end{array}$ & $\begin{array}{l}0.02 \\
(0,0.05)\end{array}$ \\
\hline & & Urogymnus asperrimus & - & - & - & - & $\begin{array}{l}0 \mathrm{~ns} \\
(0,0.02)\end{array}$ & $\begin{array}{l}0 \\
(0,0.01)\end{array}$ & - \\
\hline & \multirow[t]{3}{*}{ Serranidae } & Epinephelus lanceolatus & 0 & 0 & 0 & 0 & $0 \mathrm{~ns}$ & $\begin{array}{l}0 \\
(0,0.02)\end{array}$ & $\begin{array}{l}0 \\
(0,0.01)\end{array}$ \\
\hline & & Plectropomus areolatus & $\begin{array}{l}0.19 \mathrm{~ns} \\
(0,1.37)\end{array}$ & 0 & - & - & 0 & 0 & 0 \\
\hline & & P. laevis & $\begin{array}{l}2.44 \mathrm{~ns} \\
(0,7.43)\end{array}$ & 0 & - & - & $\begin{array}{l}1.65 \mathrm{~ns} \\
(0,5.99)\end{array}$ & 0 & $\begin{array}{l}0.95 \\
(0,3.36)\end{array}$ \\
\hline & Scaridae & Bolbometopon muricatum ${ }^{\mathrm{b}}$ & $\begin{array}{l}0.5 \mathrm{~ns} \\
(0,3.68)\end{array}$ & 0 & - & - & $0 \mathrm{~ns}$ & $\begin{array}{l}0.15 \\
(0,1.12)\end{array}$ & $\begin{array}{l}43.4 \\
(8.52,124.9)\end{array}$ \\
\hline \multirow[t]{10}{*}{ NT } & \multirow[t]{5}{*}{ Carcharhinidae } & Carcharhinus amblyrhynchos & $\begin{array}{l}1.76 \mathrm{~ns} \\
(0,5.89)\end{array}$ & $\begin{array}{l}9.72 \\
(0,29.03)\end{array}$ & $\begin{array}{l}1.17<* * * \\
(0,3.40)\end{array}$ & $\begin{array}{l}21.21 \\
(11.5,35.6)\end{array}$ & $\begin{array}{l}0.51<* * * \\
(0,2.73)\end{array}$ & $\begin{array}{l}82.74 \\
(52,119)\end{array}$ & $\begin{array}{l}386.6 \\
(247,560)\end{array}$ \\
\hline & & C. galapagensis & $\begin{array}{l}0.14 \mathrm{~ns} \\
(0,1.79)\end{array}$ & $\begin{array}{l}0.39 \\
(0,2.58)\end{array}$ & $\begin{array}{l}1.84<* * \\
(0,7.08)\end{array}$ & $\begin{array}{l}21.61 \\
(6.9,48.9)\end{array}$ & - & - & $\begin{array}{l}2.21 \\
(0,7.52)\end{array}$ \\
\hline & & C. melanopterus & $\begin{array}{l}3.8 \mathrm{~ns} \\
(0,8.96)\end{array}$ & $\begin{array}{l}4.4 \\
(0,14.20)\end{array}$ & 0 & 0 & $\begin{array}{l}2.86 \mathrm{~ns} \\
(0,7.86)\end{array}$ & $\begin{array}{l}5.53 \\
(0.46,16)\end{array}$ & $\begin{array}{l}20.38 \\
(9.51,35.24)\end{array}$ \\
\hline & & Galeocerdo cuvier & 0 & 0 & $0 \mathrm{~ns}$ & $\begin{array}{l}0.1 \\
(0,0.55)\end{array}$ & 0 & 0 & $\begin{array}{l}0.07 \\
(0,0.51)\end{array}$ \\
\hline & & Triaenodon obesus & $\begin{array}{l}9.11 \mathrm{~ns} \\
(1.7,18)\end{array}$ & $\begin{array}{l}17.27 \\
(4.6,34.9)\end{array}$ & $\begin{array}{l}2.82<* * * \\
(0,8.41)\end{array}$ & $\begin{array}{l}23.83 \\
(15.1,33.2)\end{array}$ & $\begin{array}{l}7.14<* * * \\
(1.1,16)\end{array}$ & $\begin{array}{l}57.39 \\
(42,74.1)\end{array}$ & $\begin{array}{l}53.07 \\
(29.8,87.54)\end{array}$ \\
\hline & Myliobatidae & Aetobatus narinari & $\begin{array}{l}4.58 \mathrm{~ns} \\
(0,12.36)\end{array}$ & $\begin{array}{l}0.99 \\
(0,5.25)\end{array}$ & $\begin{array}{l}5.78 \mathrm{~ns} \\
(1.4,12)\end{array}$ & $\begin{array}{l}8.67 \\
(2.3,16.97)\end{array}$ & $\begin{array}{l}4.27 \mathrm{~ns} \\
(0,11.4)\end{array}$ & $\begin{array}{l}2.37 \\
(0.45,4.98)\end{array}$ & $\begin{array}{l}17.61 \\
(7.11,30.96)\end{array}$ \\
\hline & Mobulidae & Manta alfredi & 0 & 0 & $\begin{array}{l}1.12 \mathrm{~ns} \\
(0,3.15)\end{array}$ & $\begin{array}{l}3.17 \\
(0,8.81)\end{array}$ & 0 & 0 & $\begin{array}{l}23.14 \\
(4.70,62.6)\end{array}$ \\
\hline & \multirow[t]{2}{*}{ Serranidae } & Hyporthodus quernus & - & - & $0<* * *$ & $\begin{array}{l}7.21 \\
(2.2,13.5)\end{array}$ & - & - & - \\
\hline & & Plectropoтus leopardus & $\begin{array}{l}0.34 \mathrm{~ns} \\
(0,2.38)\end{array}$ & 0 & - & - & 0 & 0 & - \\
\hline & Total & All taxa pooled & $\begin{array}{l}2.06 \mathrm{~ns} \\
(0.3,5.2)\end{array}$ & $\begin{array}{l}2.69 \\
(0.40,6.57)\end{array}$ & $\begin{array}{l}1.21<* * \\
(0.1,3.3)\end{array}$ & $\begin{array}{l}7.80 \\
(3.46,14.3)\end{array}$ & $\begin{array}{l}1.78<* * \\
(0.3,4.3)\end{array}$ & $\begin{array}{l}9.19 \\
(5.66,13.7)\end{array}$ & $\begin{array}{l}32.89 \\
(17.88,56)\end{array}$ \\
\hline
\end{tabular}

Note that units for mean densities can be converted to individuals ha ${ }^{-1}$ by dividing by 100

Islands are grouped by region and population status (Inhabited vs. Uninhabited). Values are mean density $\mathrm{km}^{-2}$ with lower and upper $95 \%$ confidence intervals identified in parentheses Confidence intervals were omitted for species where the resampled mean abundance was equal to 0 . Regions outside of the biogeographic range of a species are identified with a dash. Regional island groups with significantly higher resampled abundance values are identified with a $<$ or $>$ sign

Significance is given as: $* p<0.05 ; * * p<0.01 ; * * p<0.001$; and $n s$ not significant

a 2011 IUCN red list categories: $E N$ endangered, $V U$ vulnerable, $N T$ near threatened

${ }^{\mathrm{b}}$ NOAA Species of Concern 


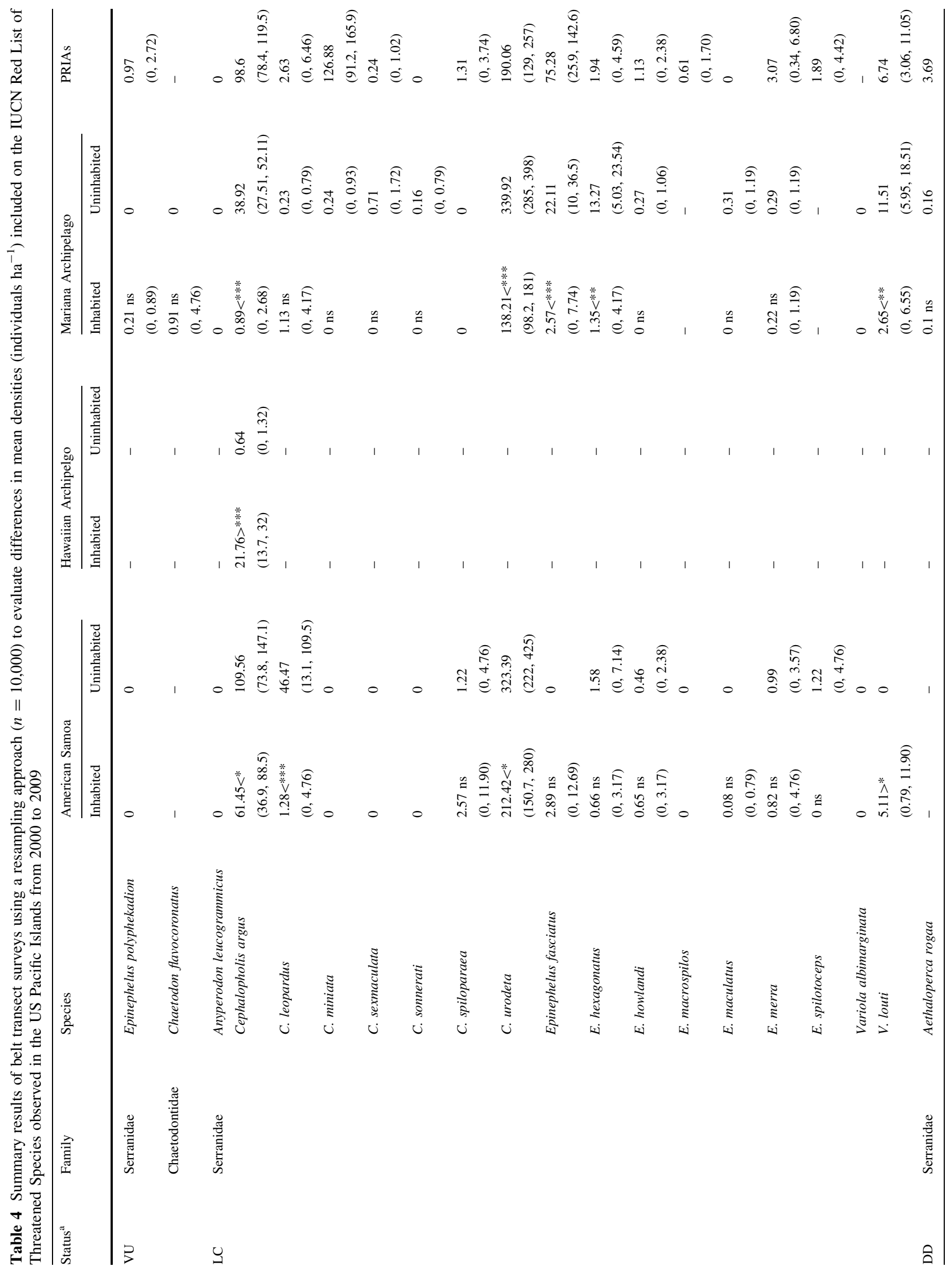




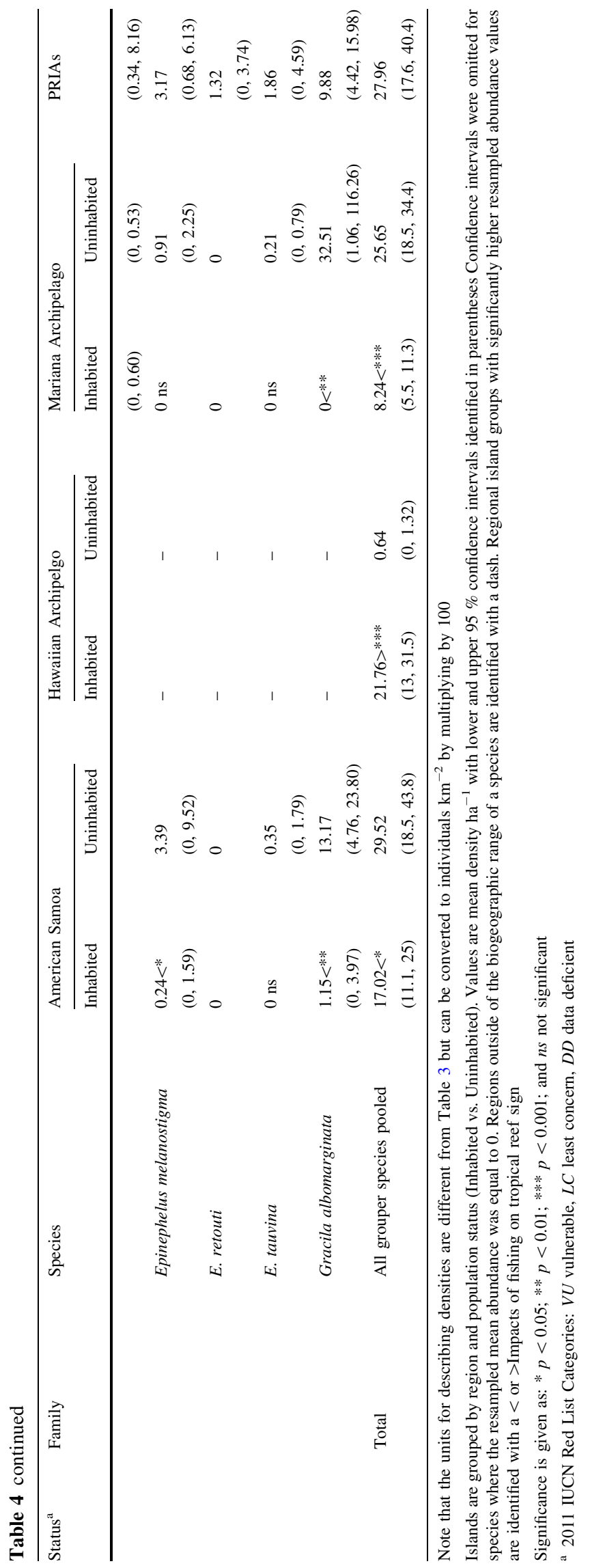

12); no individuals were recorded at uninhabited islands within the archipelago. In the Mariana Archipelago, 6 of the 22 grouper species were recorded in higher densities at uninhabited islands and no grouper species was more abundant at inhabited islands. In the Hawaiian Archipelago, the nonnative peacock hind was observed at significantly greater $(p<0.001)$ densities at inhabited islands [22 individuals $\left.\mathrm{ha}^{-1}(95 \% \mathrm{CI} 14,32)\right]$, likely a persistent consequence of its deliberate introduction into the inhabited main islands (Randall 1987).

The darkfin hind (Cephalopholis urodeta, least concern) was the most abundant grouper species overall with the greatest densities (340 individuals $\mathrm{ha}^{-1} ; 95 \%$ CI 285, 399) observed at the uninhabited islands of the Mariana Archipelago. The peacock hind also was abundant in all survey regions, with the greatest densities observed at the uninhabited islands of American Samoa [110 individuals ha ${ }^{-1}$ (95\% CI 74, 147)]. The coral hind (Cephalopholis miniata, least concern) and the blacktip grouper (Epinephelus fasciatus, least concern) were abundant in the PRIA with 127 individuals $\mathrm{ha}^{-1}(95 \%$ CI 91,166$)$ and 75 individuals $\mathrm{ha}^{-1}$ (95\% CI 26, 143) observed, respectively. These same species were rare or not observed at the inhabited islands of the American Samoa and Mariana Archipelagoes.

\section{Density of high-risk, small-bodied species}

The camouflage grouper (Epinephelus polyphekadion) and the yellow-crowned butterflyfish were the only two smallbodied species listed as vulnerable, the second-highest risk category included in this study. Camouflage grouper were most abundant in the PRIA [1 individual ha ${ }^{-1}$ (95\% CI 0, 3 ). The yellow-crowned butterflyfish, typically observed at depths greater than $30 \mathrm{~m}$ in the Mariana Archipelago, was recorded at a single site and depth less than $30 \mathrm{~m}$.

\section{Discussion}

Overexploitation is generally considered the primary threat facing coral reef fishes (Friedlander and DeMartini 2002; Reynolds et al. 2002, 2005; Dulvy et al. 2003; DeMartini et al. 2008). Although there are no documented cases of global marine fish extinctions, marked declines have occurred in several species, some of which are considered to be extinct at local or regional scales (Dulvy et al. 2003). Growing concerns over the status of many species led the IUCN to evaluate the conservation status of 1,326 species of marine fishes, 45 of which were recorded in the US Pacific Islands as part of the RAMP. Our aim was to complement IUCN evaluation efforts by providing the first large-scale assessment of IUCN-listed species in the tropical US Pacific Islands. Data included in this study are 
substantial, representing 9 yrs of survey effort, including 40 islands spanning a large portion of the tropical Pacific. From these efforts, three key findings emerge: (1) the diversity and density of IUCN-listed species in the US Pacific Islands varied across individual islands and at a regional scale; (2) mean densities significantly differed between uninhabited and inhabited islands-densities were greater in uninhabited versus inhabited regions in $78 \%$ of 23 total cases for which data were available; and (3) IUCNlisted species were most diverse and abundant in the remote and uninhabited PRIA. Threats to these IUCN-listed species continue to include their limited distributions, popularity among fisheries, life history characteristics, and remote regional occurrence (Morris et al. 2000; Sadovy et al. 2003; Donaldson and Dulvy 2004; Sadovy 2005; Sadovy and Domeier 2005).

Widely distributed species are thought to face reduced risks of extinction compared to species with restricted ranges (Hawkins et al. 2000). Large-scale exploitation reduces population densities of a species which can lead to localized extirpations and an overall range reduction (Roberts 1995). Species with clumped population distributions and/or species that form spawning aggregations at specific and predictable times and locations are more susceptible to large-scale exploitation. In the US Pacific islands, most IUCN-listed species have patchy distributions (Tables 3, 4; Fig. 1). These heterogeneous distribution patterns were not restricted to species facing the greatest extinction risk but applied to most species regardless of their IUCN List categorization. Species with low levels of abundance or disparate populations are less resistant and resilient to perturbations and have a diminished capacity to recolonize locally extirpated populations (Cooper and Mangel 1999). These findings suggest that nearly all IUCN-listed species recorded in the US Pacific Islands may be vulnerable to large-scale exploitation or perturbations and face a greater risk of local extinction compared to species with less clumped population distributions.

Most of the IUCN-listed fish species are targets for subsistence, recreational, or commercial fisheries (Morris et al. 2000; Donaldson and Sadovy 2001; Sadovy et al. 2003; Donaldson and Dulvy 2004; Robbins et al. 2006). Some species such as bumphead parrotfish might be especially vulnerable because they are also considered trophy bycatch within multi-species fisheries, thus leading to rapid and little documented rates of population decline (Dulvy et al. 2003; Dulvy and Polunin 2004). Sharks, groupers, humphead wrasse, and bumphead parrotfish accounted for more than $80 \%$ of the IUCN-listed species observed in the US Pacific islands during RAMP surveys. These species are important in structuring fish and benthic communities through their roles as influential competitors and predators on coral reefs (Roberts 1995; Bascompte et al. 2005; Estes et al. 2011). We did not observe most conspicuous large-bodied species of sharks and groupers except at remote and uninhabited islands (Tables 3, 4; Fig. 1). Large-bodied highly mobile species such as sharks showed the greatest differences in abundance between inhabited and uninhabited islands in the Hawaiian and Mariana Archipelagoes. Significant differences in the mean density of small-bodied grouper species were also observed, although less often. The reason for these differences is unknown, but the pattern has been documented in many marine ecosystems where fishing down large-bodied species has been followed by the exploitation of smallerbodied species (Roberts 1995; Jennings and Polunin 1996a, b; Pauly et al. 1998; Friedlander and DeMartini 2002; DeMartini et al. 2008). Importantly, there were similarities in the density patterns of these species regardless of category of extinction risk-each of the high-risk, low-risk, and data-deficient species of concern identified by IUCN showed vulnerability to exploitation as evidenced by regional comparisons of density between inhabited and uninhabited islands (Tables 3, 4).

Furthermore, we documented only three instances where greater densities of IUCN-listed species were observed at inhabited islands. These differences were most likely attributed to: (1) persistent results of deliberate introductions of the species to inhabited islands, as is the case for the peacock grouper in the Hawaiian Archipelago (Randall 1987), (2) lack of suitable juvenile habitat (e.g., lagoons with branching coral and macroalgae) for humphead wrasse at uninhabited islands of the Mariana Archipelago (Tupper 2007), and (3) lack of suitable adult habitat (e.g., reef passes or lagoons) for the yellow-edged lyretail grouper at uninhabited islands in American Samoa (Randall and Brock 1960; Myers 1999). Despite some speciesspecific differences, the life history characteristics common among a majority of the IUCN-listed species recorded during surveys make them particularly vulnerable to overexploitation. These characteristics include slow growth, long life span, late sexual maturation, group spawning, low replenishment rates, and low natural abundance (Reynolds et al. 2002; Sadovy and Cheung 2003; Tupper 2007; Sadovy de Mitcheson et al. 2008). These life history characteristics, combined with the Pacific-wide declines of many of these species, reinforce the importance of large-scale assessments and conservation efforts.

Underwater visual census (UVC) methods are common tools used to characterize coral reef fish assemblages (Friedlander and DeMartini 2002; DeMartini et al. 2008; Sandin et al. 2008; Williams et al. 2011). Although these methods do not provide age-based demographic data used in modern stock assessments, they provide quantitative estimates of species density, size structure, and frequency of occurrence. A key advantage of UVC methods is that 
they are fishery independent and nondestructive. This is especially important when assessing species affected by overexploitation or while working in protected areas.

Recent conservation efforts in the tropical Pacific have formally protected many of the uninhabited islands of the US Pacific, including Papahānaumokuākea (Northwestern Hawaiian Islands), Pacific Remote Islands, Marianas Trench (including many of the uninhabited islands of the Mariana Archipelago), and Rose Atoll Marine National Monuments. Such management measures should afford many of species of concern with a refuge from fishing in perpetuity. Further, the remote, uninhabited islands provide an opportunity to estimate baselines and are among the few remaining "pristine" systems where IUCN-listed species can be observed in abundance. As such, these reefs provide an unprecedented opportunity for scientists and managers to examine ecosystem function and the ecology of IUCN-listed species in the absence of direct human-caused disturbances. The knowledge gained by studying these undisturbed systems can be used to identify spawning aggregations, essential fish habitat, fish behavior, and other ecological processes that can be applied to the development recovery strategies and ecosystem-based management plans, including those for sustainable fisheries in inhabited islands.

Acknowledgments This work was conducted with the support of the NOAA Coral Reef Conservation Program, Office of Habitat Conservation, and NOAA/NSF CAMEO program. We thank the officers and crew aboard the NOAA Ships Townsand Cromwell, Oscar Elton Sette, and Hi'ialakai for logistical support. Additional logistical and personnel support was provided by the US Fish and Wildlife Service, State of Hawaii Department of Land and Natural Resources, Department of Marine and Wildlife Resources (American Samoa), Commonwealth of the Northern Mariana Islands (CNMI) Division of Fish and Wildlife, Division of Environmental Quality (CNMI), and the Guam Division of Aquatic and Wildlife Resources. We also thank E. E. DeMartini (NOAA Fisheries) and G. J. Williams (Scripps Institution of Oceanography) for their contributions throughout the development of this assessment and several anonymous reviewers for constructive comments on the manuscript.

Open Access This article is distributed under the terms of the Creative Commons Attribution License which permits any use, distribution, and reproduction in any medium, provided the original author(s) and the source are credited.

\section{References}

Allen J, Gosden C, White JP (1989) Human Pleistocene adaptations in the tropical island Pacific - recent-evidence from New-Ireland, a Greater Australian outlier. Antiquity 63:548-561

Baillie J, Groombridge B (1996) 1996 IUCN Red List of threatened animals. World Conservation Union, Gland, Switzerland

Bascompte J, Melian CJ, Sala E (2005) Interaction strength combinations and the overfishing of a marine food web. Proc Natl Acad Sci USA 102:5443-5447
Cesar HSJ, Burke LM, Pet-Soede L (2003) The economics of worldwide coral reef degradation. Cesar Environmental Economics Consulting (CEEC), Arnhem, The Netherlands

Chernick MR (2008) Bootstrap methods: a guide for practitioners and researchers, 2nd edn. Wiley-InterScience, Hoboken, New Jersey

Choat JH, Davies CR, Ackerman JL, Mapstone BD (2006) Age structure and growth in a large teleost, Cheilinus undulatus, with a review of size distribution in labrid fishes. Mar Ecol-Prog Ser 318:237-246

Colin PL (2010) Aggregation and spawning of the humphead wrasse Cheilinus undulatus (Pisces: Labridae): general aspects of spawning behaviour. J Fish Biol 76:987-1007

Cooper A, Mangel M (1999) The dangers of ignoring metapopulation structure for the conservation of salmonids. Fish Bull 97: 213-226

DeMartini EE, Friedlander AM, Sandin SA, Sala E (2008) Differences in fish-assemblage structure between fished and unfished atolls in the northern Line Islands, central Pacific. Mar Ecol-Prog Ser 365:199-215

Donaldson TJ, Sadovy Y (2001) Threatened fishes of the world: Cheilinus undulatus Ruppell, 1835 (Labridae). Environ Biol Fish 62:428

Donaldson TJ, Dulvy NK (2004) Threatened fishes of the world: Bolbometopon muricatum (Valenciennes 1840) (Scaridae). Environ Biol Fish 70:373

Dulvy N, Polunin N (2004) Using informal knowledge to infer human-induced rarity of a conspicuous reef fish. Anim Conserv 7:365-374

Dulvy NK, Sadovy Y, Reynolds JD (2003) Extinction vulnerability in marine populations. Fish Fish 4:25-64

Efron B, Tibshirani R (1986) Bootstrap methods for standard errors, confidence intervals, and other measures of statistical accuracy. Statistical Science 1:54-75

Estes JA, Terborgh J, Brashares JS, Power ME, Berger J, Bond WJ, Carpenter SR, Essington T, Holt RD, Jackson JBC, Marquis RJ, Oksanen L, Oksanen T, Paine RT, Pikitch E, Ripple WJ, Sandin SA, Scheffer M, Schoener TW, Shurin JB, Sinclair ARE, Soulé ME, Virtanen R, Wardle DA (2011) Trophic downgrading of Planet Earth. Science 333:301-306

Friedlander AM, DeMartini EE (2002) Contrasts in density, size, and biomass of reef fishes between the northwestern and the main Hawaiian islands: the effects of fishing down apex predators. Mar Ecol-Prog Ser 230:253-264

Friedlander AM, Sandin SA, DeMartini EE, Sala E (2010) Spatial patterns of the structure of reef fish assemblages at a pristine atoll in the central Pacific. Mar Ecol-Prog Ser 410:219-231

Froese R, Pauly D (2010) FishBase. Available from www.fishbase.org (accessed December 2010)

Hawkins J, Roberts C, Clark V (2000) The threatened status of restricted-range coral reef fish species. Anim Conserv 3:81-88

IUCN (2011) IUCN Red List of Threatened Species. IUCN, Gland, Switzerland

Jackson JBC, Kirby MX, Berger WH, Bjorndal KA, Botsford LW, Bourque BJ, Bradbury RH, Cooke R, Erlandson J, Estes JA, Hughes TP, Kidwell S, Lange CB, Lenihan HS, Pandolfi JM, Peterson CH, Steneck RS, Tegner MJ, Warner RR (2001) Historical overfishing and the recent collapse of coastal ecosystems. Science 293:629-638

Jennings S, Polunin NVC (1996a) Impacts of fishing on tropical reef ecosystems. Ambio 44-49

Jennings S, Polunin N (1996b) Effects of fishing effort and catch rate upon the structure and biomass of Fijian reef fish communities. J Appl Ecol 33:400-412

Jennings S, Kaiser MJ (1998) The effects of fishing on marine ecosystems. Adv Mar Biol 34:201-352 
Mace GM, Collar NJ, Gaston KJ, Hilton Taylor C, Akcakaya HR, Leader Williams N, Milner Gulland EJ, Stuart SN (2008) Quantification of extinction risk: IUCN's system for classifying threatened species. Conserv Biol 22:1424-1442

Morris AV, Roberts CM, Hawkins JP (2000) The threatened status of groupers (Epinephelinae). Biodivers Conserv 9:919-942

Myers RA, Worm B (2003) Rapid worldwide depletion of predatory fish communities. Nature 423:280-283

Myers RF (1999) Micronesian reef fishes: a field guide for divers and aquarists. Coral Graphics, Barrigada, Guam

National Research Council (1995) Science and the Endangered Species Act. National Academy Press, Washington, D.C. Xiii, p 271

Pauly D, Christensen V, Dalsgaard J, Froese R, Torres F (1998) Fishing down marine food webs. Science 279:860-863

R Core Team (2012) R: a language and environment for statistical computing. R Foundation for Statistical Computing, Vienna, Austria. http://www.Rproject.org/

Randall JE (1987) Introductions of marine fishes to the HawaiianIslands. Bull Mar Sci 41:490-502

Randall JE (2005) Reef and shore fishes of the South Pacific; New Caledonia to Tahiti and the Pitcairn Islands. University of Hawaii Press, Honolulu, Hawaii

Randall JE (2010) Shore fishes of Hawaii. University of Hawaii Press, Honolulu, Hawaii

Randall JE, Brock VE (1960) Observations on the ecology of epinepheline and lutjanid fishes of the Society Islands, with emphasis on food habits. Trans Am Fish Soc 89:9-16

Reynolds JD, Dulvy NK, Roberts CM (2002) Exploitation and other threats to fish conservation. In: Hart PJB, Reynolds JD (eds) Handbook of fish biology and fisheries, vol 2. Blackwell Publishing, Oxford, UK, pp 319-341

Reynolds JD, Dulvy NK, Goodwin NB, Hutchings JA (2005) Biology of extinction risk in marine fishes. Proc R Soc B 272:2337-2344

Richards BL, Williams ID, Nadon MO, Zgliczynski BJ (2011) A towed-diver survey method for mesoscale fishery-independent assessment of large-bodied reef fishes. Bull Mar Sci 87:55-74

Robbins W, Hisano M, Connolly S, Choat J (2006) Ongoing collapse of coral-reef shark populations. Curr Biol 16:2314-2319
Roberts C (1995) Effects of fishing on the ecosystem structure of coral reefs. Conserv Biol 9:988-995

Rodrigues ASL, Pilgrim JD, Lamoreux JF, Hoffmann M, Brooks TM (2006) The value of the IUCN Red List for conservation. Trends Ecol Evol 21:71-76

Rohmann S, Hayes J, Newhall R, Monaco M, Grigg R (2005) The area of potential shallow-water tropical and subtropical coral ecosystems in the United States. Coral Reefs 24:370-383

Sadovy Y (2005) Trouble on the reef: the imperative for managing vulnerable and valuable fisheries. Fish Fish 6:167-185

Sadovy Y, Cheung WL (2003) Near extinction of a highly fecund fish: the one that nearly got away. Fish Fish 4:86-99

Sadovy Y, Domeier M (2005) Are aggregation-fisheries sustainable? Reef fish fisheries as a case study. Coral Reefs 24:254-262

Sadovy Y, Kulbicki M, Labrosse P, Letourneur Y, Lokani P, Donaldson TJ (2003) The humphead wrasse, Cheilinus undulatus: synopsis of a threatened and poorly known giant coral reef fish. Rev Fish Biol Fish 13:327-364

Sadovy de Mitcheson Y, Cornish A, Domeier M, Colin P, Russell M, Lindeman K (2008) A global baseline for spawning aggregations of reef fishes. Conserv Biol 22:1233-1244

Sandin SA, Smith JE, DeMartini EE, Dinsdale EA, Donner SD, Friedlander AM, Konotchick T, Malay M, Maragos JE, Obura D, Pantos O, Paulay G, Richie M, Rohwer F, Schroeder RE, Walsh S, Jackson JBC, Knowlton N, Sala E (2008) Baselines and degradation of coral reefs in the northern Line Islands. PLoS One 3(2):e1548. doi:10.1371/journal.pone. 0001548

Tupper M (2007) Identification of nursery habitats for commercially valuable humphead wrasse Cheilinus undulatus and large groupers (Pisces : Serranidae) in Palau. Mar Ecol-Prog Ser 332:189-199

Williams I, Richards B, Sandin S, Baum J, Schroeder R, Nadon M, Zgliczynski B, Craig P, McIlwain J, Brainard R (2011) Differences in reef fish assemblages between populated and remote reefs spanning multiple archipelagos across the central and western Pacific. J Mar Biol 2011:1-14

Zeller D, Booth S, Pauly D (2006) Fisheries contributions to GDP: Underestimating small-scale fisheries in the Pacific. Mar Resour Econ 21:355-374 